\title{
Challenges in Coastal Spatial Data Infrastructure implementation: A review
}

\author{
Mohammed Oludare Idrees \\ Geospatial Information Science Research Center (GISRC), Faculty of Engineering, \\ Universiti Putra Malaysia, 43400 UPM, Serdang, Selangor Darul-Ehsam, Malaysia \\ Email: dare.idrees@gmail.com
}

\section{DOI: http://dx.doi.org/10.4314/sajg.v4i4.2}

\begin{abstract}
The ability to cope with the complexity surrounding the coastal zone requires an integrated approach for sustainable socio-economic development and environmental management. The concept of integrated coastal zone management (ICZM) was advanced in response to this. In line with the success story of spatial data infrastructure (SDI), initiatives are currently emerging to develop SDI for marine and coastal environment. The aim of this paper is to review emerging initiatives so as to identify the problems faced with implementation and discuss the way forward. The result may support stakeholders, policy makers, academia, and the government to leverage on the experience of others for a robust and sustainable policy and action plans on coastal management.
\end{abstract}

Keywords: Coastal SDI, Integrated Coastal Zone Management, environmental protection, spatial planning.

\section{Introduction}

The level at which environmental issues dominate national and global forums today is an indication that the earth is environmentally under vicious threats. This fact necessitates devising integrated approach to handling the environment (Cömert, Akınc1, Şahin, \& Bahar, 2008) The role of spatial data in accomplishing this is well acknowledged, however, it requires sophisticated information infrastructure in the form of spatial data infrastructure (SDI) (Akıncı, Sesli, \& Doğan, 2012) to facilitate access, exchange and sharing of spatial data in possession of a number of producers to optimize use, management and production (Gourmelon, Georis-creuseveau, \& Tixerant, 2012). There are several definitions of SDI in literature (Wright, 2009b). According to SDI cookbook (cited by Loenen, 2006), SDI is defined as "the relevant base collection of 
technologies, policies and institutional arrangements that facilitate the availability of and access to spatial data".

SDI offers improved access to data, reduced duplication of effort in data collection and maintenance, enables interoperability between dataset, modernization of administration, risk management, and spatially enabled governance (Gourmelon et al., 2012; Strain, Rajabifard, \& Williamson, 2004a). These benefits have led to several SDI initiatives at different levels: local, regional, national, international and global levels (Cömert et al., 2008; Idrees et al., 2015) with varying developmental continuum and progress. Unfortunately, most of these SDI are focused on the terrestrial environment, with only few ones incorporating the coastal and marine environment (Gourmelon et al., 2012, Strain, 2006).

In response to environmental concerns from human activities and climate change, both of which are contributing factors to natural and anthropogenic hazards (Wright, 2009), professionals and managers of coastal and marine environment are beginning to see the need for a better understanding through coordinated cross disciplinary effort. Obviously, carefully managing coastal environment is an essential framework because of its highly rich economic, social, biological and ecological values. To facilitate this, availability of and accessibility to relevant coastal and marine spatial data is critical and have been generating interest since the start of this millennium. The 11th International Symposium for GIS and Computer Cartography for Coastal Zone Management (CoastGIS 2013 conference: Monitoring and Adapting to Change on the Coast) - 18-21 June 2013 in Victoria, British Columbia, Canada attests to the awareness of the danger unsustainable coastal practices pose to the world.

Central to this paper is a review of developing initiatives in Coastal Spatial Data Infrastructure (CSDI) through the exploration of literature sources with a view to identify efforts put in place to facilitate ease of access to up-to-date and reliable coastal spatial data, and to discuss common barriers that hinder viable implementation of roadmap to achieving integrated coastal zone management (ICZM). The study is limited to national initiative, hence regional and global initiatives will not be considered.

\section{Managing the Coast with SDI}

Longhorn (2004) defined coast as "the transitional area between the land and the soil types that surrounds all kinds of natural water masses such as sea, lake, or river". Literatures stress the enormous potential social wellbeing and economic benefits of coast to humanity (Ernsteins, 2010; 
Longhorn, 2004; Meiner, 2009) such as settlement, food, energy fishery, tourism aquaculture and transportation and climate regulation. Coastal zone is a complicated area comprising of marine and terrestrial environment (Strain, Rajabifard, \& Williamson, 2004b) which makes it difficult to manage. The complexity is further escalated with the overlapping of terrestrial geography and hydrography, temporal processes, competing interest of stakeholders, jurisdiction and legal mandates both locally and international (Strain et al., 2004b; Wu et al., 2012).

Aside the socio-economic considerations, environmental protection (Ioppolo, Saija, \& Salomone, 2013), preservation of biodiversity (Hamylton \& Prosper, 2012), and climate adaptation (Falaleeva et al., 2011; Kopke \& O’Mahony Cathal, 2011) are other issues that compel urgent needs for knowledge-driven approach to understand and manage the coast through reliable spatial information. Acknowledging the necessity for sustainable environmental management, attention is gradually shifting to a holistic spatial infrastructure that can either integrate coastal spatial data with the existing NSDI or established as a separate entity (Canessa et al., 2007; Cömert et al., 2008) depending on the stated objective of the respective government.

In managing coast, concepts such as coastal atlas, coastal GIS, coastal web, and coastal or marine SDI have been used in connection with ICZM, which is a management process itself. The overall objective is to build information system that can store coastal spatial datasets and make them available and accessible to a wider user community. The concepts varies in sophistication and functionality, however the introduction of web technology is gradually closing the gap between them. An atlas generally is a collection of maps of earth or part of it showing geographic features, locations, socioeconomic and geopolitical information while GIS emphasis on spatial data manipulation and analysis to assist decision making process. Specifically, coastal atlas is an online mapping and planning tool that enable data exploration and analysis for coastal and ocean planning tasks (Katsanevakis et al., 2011). Both coastal atlas and GIS are behind-the-scene operating tools that constitute the enabling technology component of SDIs. In fact the emergence of web services has made SDI not only for data anymore but as services.

Although the concept of coastal SDI is relative new, supporting marine and coastal management by making spatial data available and accessible have long been established (Strain 2006) through ICZM. Wu et al. (2012) reports that ICZM concept evolved to enable coastal zone to be managed using integrated approach with respect to geographic and political boundaries to ensure sustainable management. Group of Experts on the Scientific Aspects of Marine Environmental Protection (GESAMP), quoted by (Cömert et al., 2008) defined ICZM as "a process that unites 
government and the community, science and management, sectoral and public interests in preparing and implementing an integrated plan for the protection and development of coastal ecosystems and resources". Having access to spatial information about coastal environment in a manner that is interoperable is essential to realizing the core objectives of ICZM. This fact paved way to the idea of building upon the experience of several NSDIs by some countries to develop information infrastructure for coastal resources. Incidentally, marine and coastal areas are still poorly managed (Strain et al., 2006) due to some barriers on the way to implementing those policies. The next section discusses some of those initiatives to identify why implementation remains an issue despite the realization of the need to manage coasts and the development in technological component of SDI. Readers are referred to (Canessa et al., 2007; Murray-O’Connor \& Cooper, 2011; Tolvanen \& Kalliola, 2008; Williamson et al., 2006) for further details on the historical background, components and requirements of developing coastal SDI.

\section{Emerging CSDI Initiatives}

In order to come to a comprehensive discovery for future improvement in planning, design and implementation of CSDI, countries considering developing coastal management tools are discussed below. It should be noted that the names given to the initiatives slightly vary from one country to another; however, the aims are similar.

\subsection{USA}

USA and Canada are respectively at the forefront in providing solution to sharing and finding geospatial data related to both terrestrial and marine environment (Wright, 2009). The efforts have greatly spurred the development of geoportals for marine and coastal areas. In the USA, some laudable initiatives were commissioned to build coastal NSDI. One of which resulted to the Ocean Planning information System (OPIS) coordinated by NOAA Coastal Service Center and the Geography Network of ESRI in partnership with government agencies, academia and the industry (Williamson et al, 2004), Strain et al., 2006). Another one is the National Biological Information Infrastructure (NBII) (Wright, 2009). Other regional tools to manage the coast of specific areas are also developing such as the Oregon Coastal Atlas (OCA) and North Coast Explorer (O’Dea, 2011).

\subsection{Canada}

The desire to effectively manage Canada's coast and ocean by making digital spatial data available and accessible to users has its foundation in mapping and coastal resources inventories 
that began with digital compilation of hard copy atlases in the early 1970s. Along the lines of advances in technology, marine GIS to support spatial analysis and later internet/web data networking were implemented in succession (Canessa et al., 2007). Canada's marine infrastructure as it is today takes its source from initiatives at both regional and national levels as building block. One of such is the Fishery and Ocean Canada sponsored project, the Inland Waters, Coastal and Ocean Information Network (ICOIN), launched in 1987. The project brought together stakeholders from government agencies and departments like Geospatial Projects Integration Office (GPIO), industry partners, academia, and nongovernmental organizations to chart strategy for Marine Cadastre and Marine spatial information Infrastructure (Canessa et al., 2007; Williamson, 2004). However, the development assumed a new dimension when the Canada Geospatial Data infrastructure (CGDI) was established in 1999 and Marine Advisory Committee constituted and formally given the authorization to establish Marine Geographic Data Infrastructure (MGDI) within the framework of CGDI to look into the concerns marine and coastal users (Strain et al., 2006, Wright 2009), and consequently the development of marine portal in GeoConnections.

\subsection{Ireland}

Until in late 1990, with the European Commission Programme on ICZM, Ireland was without national policy framework on coastal management (Falaleeva et al., 2011). The administration of Irish coastal zone was fragmented in the hands of various central and local sector of the country's administrative structure without coordination. However immediately after the EC project in which Ireland participated, along with other initiatives aimed at formalizing best practice to facilitate coastal management across EU such as European Marine Observation and data network (EMODNET) and European atlas of the sea (Murray-O'Connor \& Cooper, 2011), call was made at the national level to draft strategic implementation framework and policy for coastal ICZM. The aim was to facilitate integration of decision making process, remove obstacles created by sectoral approach to coastal management and to eliminate land and marine divide. Paradoxically, up till 2008, the draft policy from 1997 was not formally adopted due to lack of political and administrative support at the national level (Kopke \& O’Mahony Cathal, 2011); implementation was limited to local scale. This was attributed to lack of cooperation, funding, and absence of formal mechanism for interaction, knowledge exchange and experience sharing (Falaleeva et al., 2011; Murray-O'Connor \& Cooper, 2011). In 2006, university-based researchers established a network that serve as a platform for interaction between communities and practitioners involved in ICZM. The platform facilitated the development of web-based Marine Irish Digital Atlas (MIDA) 
developed jointly by University College Cork and University of Ulster, Coleraine, in 2011 (O'Dea, Dwyer, Cummins, \& Wright, 2011) for Ireland.

\subsection{Australia}

An update was made to Australia SDI vision in 2001(Strain et al., 2004b) to improve management of coastal zones. In pursuance of this, the 2002 project "Defining and Developing a Marine Cadastre for Australia" was launched (IP Williamson, 2004) with the aim of establishing information infrastructure that will enhance decision making process and enable integrated approach to managing the marine environment. Systems like Marine SDI and Marine Cadaster are tools for managing marine information in Australia (Strain et al., 2006).

\subsection{France}

Implementation of CSDI started in France since 2000 with the sole aim of improving access and sharing of spatial data related to marine and coastal environment (Gourmelon et al., 2012). Although the initiative was not specifically labeled SDI, and is developed in isolation of existing system (Strain et al., 2006), it shares similar attributes of SDI. Initiatives such as BOSCO, developed in 1998 Observatoire du Littoral in 2004, Geolitoral in 2007 (Gourmelon et al., 2012), and Sextant in 2013 (Bris et al., 2013) have been developed to monitor and enhance knowledge of the physical processes of the coastal environment. These efforts increase the volume of data collection about coastal areas, yet the public actors still suffer insufficient access to information. This situation is said to be improving in recent time, thanks to regional initiatives such as INSPIRE and other national policy on climate change.

\subsection{Japan}

In Japan, Guideline for Integrated Coastal Management Plan was adopted in 2000 at the Grand Design for the 21st Century Promotion Liaison Conference (GD21PLC) (Wakita \& Yagi, 2013). The guideline was formulated by government ministries and agencies that have business with coastal management with the responsibility of managing coastal areas vested into the hands of different tiers of government (national, prefecture and municipal). Ironically, the policy is not binding on local governments which result to absence of initiatives at the local level to develop system for integrated management of the coast. 


\subsection{Indonesia}

The government of Indonesia launched a national initiative aimed at managing the use and exploitation of resources within the marine and coastal areas. The programme code named Marine and Coastal Resources management Project (MCRMP) assembled inter-institutional groups (Technical Advisory Group - TAG) with the responsibility of producing guideline (technical and institutional) to developing national SDI focusing on marine and coastal datasets. TAG constituted Technical Working Group (TWG) comprising of six different bodies from ministries, government agencies and experts in the field. Accordingly, operational sphere of each group were defined in line with the following assignments: communication and information, clearinghouse, database standard, thematic map, custodianship and human resources. The outcome of the programme produced several documents, specifications and recommendations for developing CSDI for Indonesia (Wahyu, Pramono, \& Purnawan, 2010).

\subsection{China}

Since early 1990s, China has enacted national laws to manage coastal resources and control environmental pollution ( $\mathrm{Wu}$ et al., 2012). However, China's political structure implements state strategy to sustainable development, hence promotes effective implementation of ICZM at provincial level. Shandong promulgated provincial law in line with the national laws and completed information management system for coastal land and sea area management under the title ICZM. The institutional arrangement comprises of governmental agencies, assessment institutions, advisory committee and other support groups. The framework incorporate spatial planning scheme to solve conflicting multi-use of marine and coastal areas. Issues of utmost considerations include marine functional zoning, coastal protection and utilization, coastal zone land-use planning, marine protected area planning, and port and harbor planning.

\subsection{Italy}

In line with European Union programmes directed at preserving biodiversity, protecting habitats and sustainable environmental management, Habitat Directive was made into law through Presidential Decree no. 357/97 (Ioppolo et al., 2013) with regional authorities legally empowered to act in that direction (Malavasi, Santoro, Cutini, Acosta, \& Carranza, 2013). The local authority can assume the role of administrator in accordance with national law or promulgate its own legislation. This has enable province like Medio Campidano (Sardinia, Italy) to formulate PSSE (Sustainable Development and Eco-tourism Programme) as a local economic-environmental planning tool as part of an action plan to draw attention to innovative forms of integrated territorial management of 
coastal area focusing on eco-tourism and environmental protection from ICZM point of view. The programme was completed in January, 2012.

\subsection{Seychelles}

Seychelles, located in the western Indian Ocean comprises of 115 islands, have been concerned with coastal zone management policy since 1960 following the creation of Nature conservation Board (Hamylton \& Prosper, 2012). Since its creation in 1989, the Ministry of Environment along with other government agencies and other institutions has collectively been responsible for managing Seyschelles vast coast areas. Although the level of implementation of ICZM varies among the islands, they are bounded by the same legislation and always work together for sustainable coastal resource management. In the light of this, the joint project comprising Seychelles Government Department of Environment, Cambridge Coastal Research Unit, Cambridge University, UK and Khaled bin Sultan Living Oceans Foundation (LOF) in 2005 moved ICZM practices from mere GIS database to Seychelles Viewer application within the GIS Data Portal for managing Amirante marine and coastal areas.

\section{Discussion}

Few countries are gearing towards developing SDI dedicated to managing marine and coastal resources in a sustainable manner. Looking at the pace of progress, it is apparent that the development of CSDI concept is still at infancy, which is by extension, a tool to improve availability, access and sharing of spatial data related to marine and coastal environment, internationally defined as integrated coastal management (Gourmelon et al., 2012). Table1 presents summary of nations' experience at both national and regional levels, highlighting the needs that motivates CSDI, availability of tools to store and share spatial data, and the challenges impeding effective implementation. A "yes" in the 'System developed' column indicates that a platform to facilitate data distribution and networking is available while a "No" means it is not available. Information in the table was extracted from the referenced sources. It could be observed that both the developed nations and less developed ones are keen on having information tool to facilitate integrated coastal management. Although the factors and needs that motivate the initiation vary slightly from one country to another, the objective remains the same - sustainability. 
Table 1: Summary of selected national CSDI initiatives towards integrated coastal management

\begin{tabular}{|c|c|c|c|c|c|}
\hline 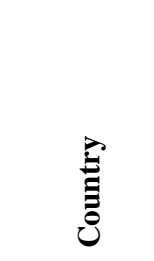 & 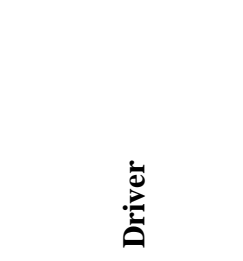 & 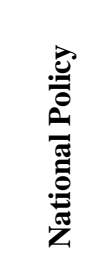 & 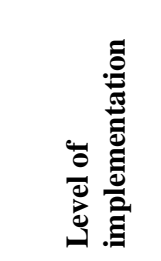 & 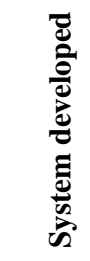 & Implementation problems \\
\hline USA & $\begin{array}{l}\text { Access to data \& } \\
\text { information } \\
\text { management of } \\
\text { coasts }\end{array}$ & Yes & $\begin{array}{l}\text { National \& } \\
\text { Provincial }\end{array}$ & Yes & $\begin{array}{l}\text { - Technical and institutional barriers } \\
\text { - Reluctance to share data }\end{array}$ \\
\hline Canada & $\begin{array}{l}\text { Good ocean } \\
\text { governance }\end{array}$ & Yes & National & Yes & - Same as above \\
\hline Ireland & $\begin{array}{l}\text { Climate } \\
\text { adaptation }\end{array}$ & Yes & National & Yes & $\begin{array}{l}\text { - Absence of a national policy and strategy for } \\
\text { adaptation, and inadequate skilled } \\
\text { professionals } \\
\text { - No financial commitment to support } \\
\text { implementation } \\
\text { - Fragmentation of government structure and } \\
\text { responsibilities of key stakeholders } \\
\text { - Lack of coordinated effort for ICZM } \\
\text { implementation at the national level } \\
\text { - Low awareness of the specifics of adaptation } \\
\text { at the local level }\end{array}$ \\
\hline Australia & $\begin{array}{l}\text { Management of } \\
\text { coastal zone, } \\
\text { access to marine } \\
\text { data and } \\
\text { interoperability }\end{array}$ & & National & Yes & $\begin{array}{l}\text { - Absence of cooperation between agencies } \\
\text { - Complex array of legislative and } \\
\text { international arrangement } \\
\text { - Confusing array of datasets and format }\end{array}$ \\
\hline France & $\begin{array}{l}\text { Access to spatial } \\
\text { data, } \\
\text { preservation of } \\
\text { coastal zone }\end{array}$ & yes & $\begin{array}{l}\text { National \& } \\
\text { Provincial }\end{array}$ & Yes & $\begin{array}{l}\text { - Organizational barriers } \\
\text { - Reluctant to share data among institutions }\end{array}$ \\
\hline Japan & $\begin{array}{l}\text { Environmental \& } \\
\text { socio-economic }\end{array}$ & Yes & National & No & $\begin{array}{l}\text { - Lack of fund, } \\
\text { - Conflicting administrative boundary of } \\
\text { coastal zone among local governments } \\
\text { - Diminished authority of the coordinating } \\
\text { agency } \\
\text { - Conflicting and overlapping interest }\end{array}$ \\
\hline Indonesia & $\begin{array}{l}\text { Exploring marine } \\
\text { and coastal } \\
\text { resources }\end{array}$ & yes & National & No & $\begin{array}{l}\text { - Variability and dynamicity of marine spatial } \\
\text { data } \\
\text { - Stakeholders' cooperation }\end{array}$ \\
\hline China & $\begin{array}{l}\text { Resource } \\
\text { management }\end{array}$ & Yes & Provincial & Yes & $\begin{array}{l}\text { - Unclear jurisdiction } \\
\text { - Irresponsibility of institutions } \\
\text { - Poor coordination } \\
\text { - Lack of public participation }\end{array}$ \\
\hline Italy & $\begin{array}{l}\text { Eco-tourism \& } \\
\text { environmental } \\
\text { protection }\end{array}$ & Yes & Provincial & No & $\begin{array}{l}\text { - Restriction placed on local authority by law } \\
\text { - Long term commitment } \\
\text { - Lack of operational capacity }\end{array}$ \\
\hline Seychelles & $\begin{array}{l}\text { Environmental } \\
\text { management \& } \\
\text { marine } \\
\text { conservation }\end{array}$ & Yes & Provincial & Yes & $\begin{array}{l}\text { - Access to spatial data } \\
\text { - Inadequate resources (human \& material) } \\
\text { - Maintaining \& updating the system/data }\end{array}$ \\
\hline
\end{tabular}


What drive the need for CSDI according to this study arises from three major issues of national importance - environmental management, economic development, and social well-being. With countries like USA, Canada, and Australia prioritizing good governance through access to spatial data (a social dimension), and environmental management, Ireland and France emphasize on adaptation to climate change in line with international and regional directives (Strain et al., 2006, Falaleeva et al., 2011). In the case of Italy, Japan, China, Seychelles and Indonesia, balancing economic development and environmental protection are the over aching challenges that necessitate having coastal SDI. A common trend in the motivations is that no nation envisions a solitary benefit. This is because the three variables function interactively, neglecting one could risk the normal functioning of the others.

Policy formulation is unarguably not a problem to nations aspiring to develop tools to manage coastal zone. Whether it is called ICZM or CSDI, all the nations reviewed have policy on ground to facilitate integrated method for collective action on natural and anthropogenic process that may threaten the sustainable future of the coastal environment in compliance with international obligation (Gourmelon et al., 2012; Kopke \& O’Mahony Cathal, 2011). Beyond the paper document lays the task of putting the plan into action, a challenge that will further be discussed under the implementation problems.

Currently there are proactive moves towards integrated coastal zone management that would potentially result to developing national marine or coastal SDI. Since all the concepts have the same goal, this study do not make a distinction with respect to each country but to discuss the three levels of implementation based on the author's classification, and treat peculiar problems associated with each level.

The first level, which the author refers to as advanced level comprises of the USA, Canada and Australia. The trio is a group of countries with national agenda, policy and programmes for building coastal SDI at federal and local levels that is interoperable with existing national SDI of the respective country for effective governance, sustainable development and scientific understanding of the earth processes. To have a system that will encompasses the terrestrial and marine spatial data, three characteristic problems still pose as hindrance similar to those experienced with SDI (Longhorn, 2004). These barriers are technical, institutional (such as intellectual property right) and interagency cooperation. The technical problems include data format, standards and interoperability, undoubtedly are receiving necessary attention (Gourmelon et al., 2012). It is noteworthy that these countries have successfully developed tools that are important 
manifestation of innovative CSDI implementation from which lesson can be learnt by other countries with similar national agenda.

The second classification, advancing group, comprises of Ireland, France and Seychelles. While these countries have policies and have developed tools to enhance access to marine and coastal spatial data, the objectives remain the same - understanding earth processes and managing coastal resources. This notwithstanding, reluctance to share data, lack of coordinated effort, low awareness, absence of financial commitment, access to spatial data and inadequate resources are their common challenges. Even Ireland with MIDA, reported as a prototype of national coastal SDI (O'Dea et al., 2011), has no national policy and strategy for climate adaptation. In the case of Seychelles with about 115 islands (Hamylton \& Prosper, 2012), having a system to facilitate access to spatial data to manage coastal environment is in progress. Amitante islands web-based coastal data viewer developed is an initiative with national agenda. Meanwhile, inadequate resources and continue financial commitment are major challenges. Developing tool for accessing marine and coastal spatial data by Irish and French governments without coordinated effort for ICZM at national level signals lack of commitment on the part of the government.

The third category consists of China, Japan, Italy and Indonesia. All these countries have policies directed towards how to manage the abundant resources in their coasts for economic development and environmental protection. Conversely, none of them have developed system or tool to facilitate that. Failure to implement policy may be attributed to government structure (Cömert et al., 2008; Falaleeva et al., 2011; Kopke \& O’Mahony Cathal, 2011) which dictate how government function, how responsibility are assigned and how services are rendered. Key issues common to this group of countries is conflicts of interest, administrative boundaries and legal instruments. While China does not overtly claim lack of fund and operational capacity as hindrance to implementing CSDI like its counterparts, irresponsibility of institutions, poor coordination and absence of public participation are major obstacles. Beside the institutional challenges, dealing with the variability and dynamicity of marine spatial data is a concern, especially to Indonesia. With the exception of Indonesia, this group and the advancing category have national policies that much more favour implementation of coastal management at the local level. This could be due to cultural or political polarity which exerts undue influence on decision making process.

Despite the fact that marine and coastal environment are identified as vital to national economies, it can still be observed that SDIs that manage land information in each of these three classes are well developed ahead of coastal SDIs. While some researchers adduce reasons to 
government failure to comprehend their true worth, others point out that coastal and marine environment are assumed to be less economically important than the terrestrial environment (Horstman et al., 2009). Furthermore, the dynamicity and multi-dimensionality of the environment makes data collection and updating difficult and costly (Cömert et al., 2008; Katsanevakis et al., 2011; Tolvanen \& Kalliola, 2008). The complex array of geospatial, biophysical and meteorological dataset and how to integrate them involve a number of sensors. This is why developing coastal SDIs receive late attention compare to its land-based equivalent. Another reason coastal SDI lags behind SDIs for land information is the sectoral approach to the use of coastal resources and the resultant fragmented policy making (Cooper et al., 2010; Murray-O'Connor \& Cooper, 2011). Interest in marine and coastal resources management involve a number of professionals including those in the engineering, natural sciences, social sciences, economics, etc. who are not effectively engaged to develop participatory and integrated policies. Last but not the least is the scale of interference and complexity of legislative arrangement. Coastal management is often a large scale project comprising of technical, financial and legal components (Cömert et al., 2008; Horstman et al., 2009). Cost of embarking on such large scale project and legislative barriers at both national and international levels discourage early response to developing coastal SDIs at the same pace with SDIs for land information. Nevertheless, there is increasing global consciousness to finding solution the spate of natural and human-induced disasters resulting from mismanagement of marine and coastal environment using integrated approach that is forcing nations to consider coastal SDIs.

Marine and coastal management is a dynamic process that requires an in-depth understanding of earth processes beyond the coastal environment. To achieve the expected goals of the international concept of ICZM, it is important that nations identify problems constituting setback to implementing policies so as to come to a common term on issues of differences for the mutual benefits of all. The idea of sacrificing the environment for economic prosperity can no longer be seen as a smart decision since advert impact on the environment will definitely affect social wellbeing and economic development. Again nations should look further than isolated and disjointed approach to managing the coast by developing standards that will enhance interoperability. Coastal management often needs an integrative approach that combines various spatial data produced by different organizations. Ensuring good access to these invaluable data can possible through multiparty collaboration sharing common standard of geographic information and technology infrastructure developed by International standards like the ISO/OGC, International Hydrographic Organisation (IHO), International Hydrographic Bureau (IHB) and other local bodies to enable data collection and storage, discovery and delivery, and metadata for cataloguing, discovery and retrieval (Cooper et al., 2010; Katsanevakis et al., 2011). This will guarantee holistic 
approach to understanding the earth processes and managing the coast and marine environment for sustainable development.

\section{Conclusion}

In this study, national initiatives on ICZM through the development of marine or coastal SDI were reviewed. The result shows that the development of marine or coastal SDI is gaining the required attention. Regional and sub-regional collaborative efforts seem to gain more supports ahead of national initiatives. Although more national strides are receiving supports as revealed in this study, attaining the standard implementation pedestal that will measurable global uniqueness remain a challenge due to the problems discussed in this paper. The problems are of varying categories between the starters and those that have advanced both in terms technical resources and policy. However, experiences of the advanced nations like the USA, Canada and Australia can be leveraged upon by countries nurturing the same idea especially in Africa where regional agenda on sustainable coastal management dominates national interest. A bottom-up strategy that considers marine governance structures in which all public and stakeholders views are engaged right from local to regional, national, and global levels to create awareness of the benefits of multilateral geographic information partnership would likely favour accelerated development for enduring policy implementation where responsibilities are consolidated among nations whose activities in the coast will definitely have impact beyond their shore, as opposed to global approach proposed by Cooper et al. (2010). This study will be useful to emerging and future initiatives by learning through the experiences of the pioneer CSDI to design strategic plans that will facilitate efficient coastal governance. Not only that, it will provide future policy makers the opportunity to audit their institutional and technical capacity in order plan how best to counter or at least minimize the similar challenges.

\section{Acknowledgement}

The Author acknowledges the anonymous reviewers for their invaluable comments, contributions and suggestions to improve this paper.

\section{References}

Akıncı, H., Sesli, F. A., \& Doğan, S. (2012). Implementation of a web services-based SDI to control and manage private ownership rights on coastal areas. Ocean \& Coastal Management, 67, 54-62. doi:10.1016/j.ocecoaman.2012.06.004

Canessa, R., Butler, M., Leblanc, C., Stewart, C., \& Howes, D. (2007). Spatial information infrastructure for integrated coastal and ocean management in Canada. Coastal Management, 35(1), 105-142. doi:10.1080/08920750600970537 
Cömert, Ç., Akıncı, H., Şahin, N., \& Bahar, Ö. (2008). The value of marine Spatial Data Infrastructure. Fresenius Environmental Bulletin, 17(12), 2240-2249.

Cooper, P., Pepper, J., \& Osborne, M. (2010). The hydrographic and oceanographic dimension to marine spatial data infrastructure development: Developing the capacity. IHO MSDI Working Group White paper, 1-7.

Ernsteins, R. (2010). Participation and integration are key to coastal management. Science for Environment Policy, (19), 1-8.

Falaleeva, M., O’Mahony, C., Gray, S., Desmond, M., Gault, J., \& Cummins, V. (2011). Towards climate adaptation and coastal governance in Ireland: Integrated architecture for effective management. Marine Policy, 35(6), 784-793. doi:10.1016/j.marpol.2011.01.005

Gourmelon, F., Georis-creuseveau, J., \& Tixerant, M. Le. (2012). Towards a Coastal Spatial Data Infrastructure ( CSDI ) responsive to the needs of integrated coastal zone management: The GeoBretagne Experience ( France ). In Global Geospatial Conference: Spatially Enabling Government, Industry and Citizen (pp. 1-16). Quebec, Canada, 1-6 June, 2012.

Hamylton, S. M., \& Prosper, J. (2012). Development of a spatial data infrastructure for coastal management in the Amirante Islands, Seychelles. International Journal of Applied Earth Observation and Geoinformation, 19, 24-30. doi:10.1016/j.jag.2012.04.004

Horstman, E. M., Wijnberg, K. M., Smale, A. J., \& Hulscher, S. J. M. H. (2009). On the consequences of a long-term perspective for coastal management. Ocean and Coastal Management, 52(12), 593611. doi:10.1016/j.ocecoaman.2009.08.009

Idrees, M. O., Saeidi, V., \& Shariff, A. R. M. (2015). Factors explaining differences in NSDI development status between the developed and developing world. Global Journal of Engineering Science and Research Management, 2(6), 17-36.

Ioppolo, G., Saija, G., \& Salomone, R. (2013). From coastal management to environmental management: The sustainable eco-tourism program for the mid-western coast of Sardinia (Italy). Land Use Policy, 31(357), 460-471. doi:10.1016/j.landusepol.2012.08.010

Katsanevakis, S., Stelzenmüller, V., South, A., Sørensen, T. K., Jones, P. J. S., Kerr, S., ... Hofstede, R. Ter. (2011). Ecosystem-based marine spatial management: Review of concepts, policies, tools, and critical issues. Ocean and Coastal Management, 54(11), 807-820. doi:10.1016/j.ocecoaman.2011.09.002

Kopke, K., \& O’Mahony Cathal. (2011). Preparedness of key coastal and marine sectors in Ireland to adapt to climate change. Marine Policy, 35(6), 800-809. doi:10.1016/j.marpol.2011.01.008

Loenen, B. Van. (2006). Developing geographic information infrastructures. (J. de Jong, J. A. Zevenbergen, P. J. M. van Oosterom, R. W. Wagenaar, A. K. Bregt, H. J. Onsrud, \& A. Rajabifard, Eds.) (First). Deft, The Netherlands: Delft University Press.

Longhorn, R. (2004). Integrated Coastal / Marine Spatial Data Infrastructure. Retrieved January 10, 2014, from www.gisig.it/eco-imagine/full papers/Longhorn.PDF

Malavasi, M., Santoro, R., Cutini, M., Acosta, a. T. R., \& Carranza, M. L. (2013). What has happened to coastal dunes in the last half century? A multitemporal coastal landscape analysis in Central Italy. Landscape and Urban Planning, 119, 54-63. doi:10.1016/j.landurbplan.2013.06.012

Meiner, A. (2009). Integrated maritime policy for the European Union - consolidating coastal and marine information to support maritime spatial planning. Journal of Coastal Conservation, 14(1), 1-11. doi:10.1007/s11852-009-0077-4

Murray-O'Connor, H., \& Cooper, A. (2011). The role of spatial data management strategies in ICZM in Ireland. Coastal Management, 39(2), 198-221. doi:10.1080/08920753.2011.555835

O’Dea, E. K., Dwyer, E., Cummins, V., \& Wright, D. J. (2011). Potentials and limitations of Coastal Web Atlases. Journal of Coastal Conservation, 15(4), 607-627. doi:10.1007/s11852-011-0150-7

Strain, L., Rajabifard, A., \& Williamson, I. (2004). Spatial Data Infrastructure to facilitate coastal zone management. In Coastal Zone Asia Pacific Conference (pp. 1-6). Brisbane, Australia, 5-9 September, 2004.

Tolvanen, H., \& Kalliola, R. (2008). A structured approach to geographical information in coastal research and management. Ocean and Coastal Management, 51(6), 485-494. doi:10.1016/j.ocecoaman.2008.04.001 
Wahyu, S., Pramono, G. H., \& Purnawan, B. (2010). Establishment of marine and coastal spatial data infrastructure in Indonesia. In D. R. Green (Ed.), Coastal and Marine Geospatial Technologies, Coastal Systems and ContinentalMargins 13 (Vol. 13, pp. 97-103). Dordrecht: Springer Netherlands. doi:10.1007/978-1-4020-9720-1

Wakita, K., \& Yagi, N. (2013). Evaluating integrated coastal management planning policy in Japan: Why the Guideline 2000 has not been implemented. Ocean \& Coastal Management, 84, 97-106. doi:10.1016/j.ocecoaman.2013.07.012

Williamson, I. (2004). Issues in developing marine SDI. In PCGIAP Joint Workshop of WG1 and WG2 (pp. 1-12). Chengdu, China, 7-8 September 2004.

Williamson, I., Rajabifard, A., \& Andrew Binns. (2006). Challenges and issues for SDI development. International Journal of Spatial Data Infrastructures Research, 1, 24 -35.

Wright, D. J. (2009a). Remote Sensing and geospatial technologies for coastal ecosystem assessment and management. In X. Yang (Ed.), (pp. 91-112). Berlin, Heidelberg: Springer Berlin Heidelberg. doi:10.1007/978-3-540-88183-4

Wright, D. J. (2009b). Spatial Data Infrastructure for coastal environment. In X. Yang (Ed.), Remote Sensing and Geospatial Technologies for Coastal Ecosystem Assessment and Management (pp. 91-112). Berlin, Heidelberg: Springer Berlin Heidelberg. doi:10.1007/978-3-540-88183-4

Wu, X. Q., Gao, M., Wang, D., Wang, Y., Lu, Q. S., \& Zhang, Z. D. (2012). Framework and practice of integrated coastal zone management in Shandong Province, China. Ocean \& Coastal Management, 69, 58-67. doi:10.1016/j.ocecoaman.2012.07.030 